The Effects of Cross-Level Conflict: The Moderating Effects of Conflict Culture on the Group Faultlines - Performance Link

\author{
Katerina Bezrukova \\ The Wharton School \\ University of Pennsylvania \\ Philadelphia, PA 19104-6370
}

Tel: (215) 573-5726 Fax: 215-898-0401

E-mail: bezrukov@wharton.upenn.edu

\author{
Karen A. Jehn \\ The Wharton School \\ University of Pennsylvania \\ Philadelphia, PA 19104-6370
}

Tel: 215-898-7722 Fax: 215-898-0401

E-Mail: jehn@wharton.upenn.edu

January, 2002 


\title{
The Effects of Cross-Level Conflict: The Moderating Effects of Conflict Culture on the Group Faultlines - Performance Link
}

\begin{abstract}
We examine how task, relationship, and process conflicts arise from group faultlines. We define group faultlines as hypothetical dividing lines that split a group into subgroups based on the group members' attributes (adapted from Lau \& Murnighan, 1998). We further link group conflict to performance, and predict different effects for individual performance, group performance, and employee satisfaction. We also examine the moderating effect of the organizational conflict culture on the relationship between group faultlines and group conflict. We define conflict culture as employees' beliefs about the amount and intensity of a certain type of conflict (i.e. task conflict, relationship conflict, process conflict) in their work environment. We use data from 78 groups in a Fortune 500 computer firm. Future research directions and implications for managers are discussed.
\end{abstract}

Key words: group faultlines, conflict culture, and performance 


\section{The Effects of Cross-Level Conflict: The Moderating Effects of Conflict Culture on the Group Faultlines - Performance Link}

Past research and theory on diversity and conflict has provided some insights into variations in the types of diversity and conflict in organizations and groups and their impact on performance (Jehn, Northcraft, \& Neale, 1999; c.f. Williams \& O'Reilly, 1998). However, research on the effects of diversity has been characterized by inconsistent and mixed findings (Watson, Kumar, \& Michaelsen, 1993; c.f. Williams \& O'Reilly, 1998). Similarly, recent reviews on workgroup conflict have stressed that the traditional understanding of conflict as the absolute level or total amount of conflict present in groups was incomplete because it ignored the conflict culture of the organization and couldn't fully describe the nature of conflict within a group (Jehn \& Chatman, 2001). Therefore, a next generation of diversity and conflict research is needed to employ a more sophisticated diversity approach as well as a more complete conceptualization of conflict by taking into account the conflict context.

Most research on diversity in groups and organizations has looked at diversity as a composite of an individual's various demographic characteristics (c.f. Thatcher \& Jehn, 1998; c.f. Williams \& O’Reilly, 1998). From this perspective diversity has been considered as a group-level variable defined as the degree to which there is dispersion of a particular demographic characteristic in a specific population (Blau, 1977). We advance the traditional understanding of diversity by utilizing a group faultlines approach (Lau \& Murnighan, 1998; Thatcher, Jehn, \& Zanutto, 2001). Group faultlines are hypothetical dividing lines that split a group into subgroups based on two or more characteristics (adapted from Lau \& Murnighan, 1998). Group faultline theory furthers the common conceptualization of diversity by taking into account more than one demographic characteristic at a time, the way these characteristics align, and the number of possible subgroupings that emerge.

We explore the fact of group faultlines in connection to workgroup conflict. In particular, we look at the three different types of conflict that were identified in previous research 
(Jehn, 1997; Jehn, Northcraft, \& Neale, 1999; Pelled, 1996). Relationship conflict is defined as disagreement over personal issues not related to work. Task conflict is defined as disagreement about work related issues. And finally, process conflict refers to disagreement over delegation of duties and resources. The traditional understanding of conflict (the base line conflict structure) focuses on the absolute level of conflict or total amount of conflict presented within the group. We further the conceptualization of conflict by examining the effects of conflict across different levels: group and business unit (note, that groups are within a larger business unit). In particular, we examine the business unit conflict culture as a moderator of the relationship between group faultlines and group conflict. We define conflict culture as employees' beliefs about the amount and intensity of a certain type of conflict (i.e. task conflict, relationship conflict, process conflict) in their work environment.

Culture is one of the most often studied moderators in the diversity research (Jehn, 1994; Probst, Carnevale, \& Triandis, 1999). Culture refers to the individuals' fundamental beliefs regarding the desirability of behavior choices (Enz, 1988; Rokeach, 1973). It reflects, for example, preferred ways to perform individual and group tasks such as being innovative, task-oriented, or career-oriented (Jehn, 1994; Jehn, Chadwick, \& Thatcher, 1997; O'Reilly, Chatman, \& Caldwell, 1991). Two primary concerns become relevant when researchers conceptualize organizational culture: (1) the extent to which members care about culture (culture strength), and (2) the extent to which culture differs across settings (culture content) (Flynn \& Chatman, 2000; Mannix, Thatcher, \& Jehn, 2000). The content of culture, and sequentially, norms and the behaviors it supports, vary widely across business units in an organization (Bettenhausen and Murnighan, 1991; Jehn, 1994).

Furthermore, we explore the effects of group faultlines and cross-level conflict and develop hypotheses linking them to team effectiveness. We define team effectiveness in terms of three aspects: (1) the extent to which the productive output of group members meets performance standards set by the company and subjectively scored by the manager of a group (i.e. individual performance ratings), (2) the extent to which the productive 
output of a group meets performance standards set by the company based on group, business unit, and company performance (i.e. stock options, bonuses), and (3) the extent to which group members' experience in the work group is satisfying (Hackman, 1987). We propose that to the extent and direction to which group conflict influences performance would be different with respect to the particular performance outcome (e.g. individual-level performance versus group-level performance).

The major contribution of this research is that we provide further empirical testing of group faultline theory by looking at faultlines in connection to cross-level conflict (group level conflict and business unit level conflict cultures). Secondly, this is one of the first field studies that contain demographic information on 78 workgroups, as well as rich contextual data regarding group conflict and business unit conflict cultures within organization. This field site also utilizes a wide range of individual and group outcome variables not often possible to collect in studies of diversity and conflict: stock options, bonuses, and performance ratings.

\section{Research Model and Hypotheses}

Based on the group faultlines, social identity and social categorization theories, and literatures on intragroup and intergroup conflict we argue that task, relationship, and process conflicts arise from group faultlines (Jehn 1994; 1997; Lau \& Murnighan, 1998; Mannix, Thatcher \& Jehn 2001; Tajfel \& Turner, 1986). We further link group conflict to performance, and predict different effects for individual performance, group performance, and employee satisfaction drawing on the literature on organizational conflict and productivity losses (e.g. Jehn, Northcraft, \& Neale, 1999; Webber \& Donahue, 2001). From the cultural perspective we examine the moderating effect of the conflict culture (business unit variable) on the relationship between group faultlines and group conflict (O'Reilly \& Chatman 1996; O'Reilly, Chatman, \& Caldwell 1991). See Figure 1 for the research model. 


\section{Group Faultlines and Conflict}

Using coalition theory (Caplow, 1956; Komorita \& Kravitz, 1983; Mack \& Snyder, 1957; Murnighan, 1978) and Schneider's attraction-selection-attrition model of organizational membership (1983), we expand group faultline theory and propose that if many demographic attributes align in the group (e.g., two white male engineers and two black female economists), group members in each subgroup will perceive the similarity within their subgroup. Since similar members are likely to interact with each other more often and find their interactions pleasant and more desirable, they will be likely to form coalitions (Byrne, 1971; Pool, 1976). Due to the similarity among group members involved in coalition formation, the conflict within subgroups is apt to decline. However, the existence of coalitions is likely to amplify the salience of in-group/out-group membership causing strain and polarization between subgroups (Hogg, Turner, \& Davidson, 1990). Once coalitions are formed, the negative effects of stereotyping, ingroup favoritism and out-group hostility are likely to sharpen the boundary salience around coalitions and strengthen conflict between them. These group processes are likely to lead to intensification of conflict between subgroups and therefore, promote or activate intergroup conflict. In particular, we discuss and examine three types of conflict that have been identified in working groups, bicultural teams, and organizing entities (Amason, 1996; Jehn, 1997; Jehn and Jageuri, 2001; Jehn, Northcraft, and Neale, 1999; Pelled, 1996; Shah and Jehn, 1993).

Because of negative categorization processes, subgroups are likely to experience frustration, discomfort, hostility, and anxiety that can result in animosity and annoyance between individuals belonging to different subgroups, and hence, relationship conflict is likely to emerge between two or more subgroups (Jehn, 1997; Tajfel \& Turner, 1986). We expand Jehn's (1997) concept of relationship conflict within groups by defining relationship conflicts as disagreements and incompatibilities between two subgroups within a group about issues that are not task related, but that focus on personal issues. Furthermore, the more that demographic attributes align in the same way, the more salient the perceived similarities within subgroups, and the more salient the perceived differences between subgroups. The greater salience of these out-group differences is 
likely to facilitate the more intense polarization between subgroups, which will inevitably result in more fights over non-task related issues. We argue that the greater the group faultlines, the higher the level of relationship conflict between the two subgroups will be.

\section{Hypothesis 1a (H1a): The stronger the group faultline, the higher the level of relationship conflict between subgroups.}

Based on the literature on minority dissent and decision making processes in work groups, we argue that the very existence of subgroups within a group is a source of divergent thinking (De Dreu \& West, 2001). Specifically, when subgroups are formed based on alignment of group members' attributes, those members are likely to exhibit ingroup favoritism and conform to the opinion, idea, or perspective favored by their subgroup (Baron, Kerr, \& Miller, 1993). Furthermore, they are likely to have a broader range of knowledge, experience, and opinion due to intense polarization between subgroups around ideas and thoughts (e.g. Ancona \& Caldwell, 1992). This variety in knowledge and experiences can lead to disagreement among group members about group tasks (Jackson, 1992; Jehn 1995; Jehn 1997; Pelled, Eisenhardt, \& Xin, 1997). Therefore, we propose that this disagreement over group tasks will result in high levels of task conflict between subgroups within a group.

\section{Hypothesis 1b (H1b): The stronger the group faultline, the higher the level of task conflict between subgroups.}

Based on the discussion above, we argue that the greater the group faultlines, the more intense the polarization between subgroups around "different ways" of doing things, which will result in a high level of process conflict between subgroups. Process conflicts between subgroups are about logistical and delegation issues such as how task accomplishment should proceed in the work unit, who's responsible for what, and how things should be delegated (Jehn, 1997; Kramer, 1991). We propose that different approaches based on different educational backgrounds, past work experience and training, and nationality, for example, will incite process conflict across subgroups. Therefore, we hypothesize that: 
Hypothesis 1c (H1c): The stronger the group faultline, the higher the level of process conflict between subgroups.

\section{Conflict and Performance}

Relationship conflicts frequently reported are about social events, gossip, clothing preferences, political views, and hobbies (Jehn, 1997). This type of conflict often is associated with animosity and annoyance between individuals belonging to different subgroups. Relationship conflict can cause extreme negative process problems, which sometimes could lead to bullying, belittling employees, and workplace violence. These conflicts deplete energy and effort that could be expended toward task completion and consolidation around mutual goals. It has been shown that relationship conflict has negative effects and is responsible for outcomes such as increased turnover, high rates of absenteeism, decreased satisfaction, low levels of perceived performance, poor objective performance, and low commitment (Jehn, 1995; Jehn et al., 1997; Baron, 1991).

Therefore, we propose:

Hypothesis 2a (H2a): Groups with high levels of relationship conflict will have members with lower performance ratings, and will be less likely to remain together as a cohesive, cooperative whole than groups with lower levels of relationship conflict.

Hypothesis 2b (H2b): Groups with high levels of relationship conflict will have lower levels of group bonuses and stock options, and be less likely to remain together as a cohesive, cooperative whole than groups with lower levels of relationship conflict.

Hypothesis 2c (H2c): Groups with high levels of relationship conflict will have members with lower levels satisfaction, and will be less likely to remain together as a cohesive, cooperative whole than groups with low levels of relationship conflict.

Task conflict, which is focused on content-related issues, can enhance performance quality (Jehn, Northcraft, and Neale, 1999). For example, critical debate among members of two different ethnic subgroups and open discussion regarding task issues 
increases group performance because members are more likely to offer and evaluate various solutions, thus reaching optimal decisions and outcomes (Cosier and Rose, 1977;

Schweiger, Sandberg, and Rechner, 1989; Amason, 1996). However, conflict in any form can be an uncomfortable environment, decreasing individuals' perceptions of teamwork and their satisfaction (Amason and Schweiger, 1994). When members feel discomfort with the group process and dissatisfaction with the group experience, they are less likely to remain together as a cohesive, cooperative group.

Hypothesis 3a (H3a): Groups with high levels of task conflict will have members with moderate levels of individual performance, and will be less likely to remain together as a cohesive, cooperative whole than groups with low levels of task conflict.

Hypothesis 3b (H3b): Groups with high levels of task conflict will have higher levels of group bonuses and stock options, and be less likely to remain together as a cohesive, cooperative whole than groups with low levels of task conflict.

Hypothesis 3c (H3c): Groups with high levels of task conflict will have members with lower levels of satisfaction, and be less likely to remain together as a cohesive, cooperative whole than groups with lower levels of task conflict.

Jehn (1997) delineates between task and process conflict based on findings of an ethnographic study of work groups. While process conflict may seem closely related to task conflict in that the issues are related to task strategy and accomplishment, process conflict has been shown empirically to operate more like relationship conflict in its connection to performance and satisfaction in groups (Jehn, Northcraft, \& Neale, 1999; Jehn \& Mannix, 2000). Process issues can arise across ethnic subgroups, subgroups based on functional areas, or a combination of many demographic characteristics aligned. Who does something often times includes discussion about, for instance, functional expertise and skills that can feel personal, especially when related to material and human resources. Process conflict is usually associated with the resource allocation and distribution of responsibilities within the group. These processes are normally tied to 
group members' compensation and can promote competition over limited or scarce resources. People who anticipate this competition will be more anxious about their individual performance and distracted from contributing to the group's product. This is likely to result in tension within a group. Once the tension is increased, the employees are likely to become less satisfied. Therefore, we propose:

Hypothesis 4a (H4a): Groups with high levels of process conflict will have members with lower levels of individual performance, and will be less likely to remain together as a cohesive, cooperative whole than groups with lower levels of process conflict.

Hypothesis 4b (H4b): Groups with high levels of process conflict will have lower levels of group bonuses and stock options, and be less likely to remain together as a cohesive, cooperative whole than groups with lower levels of process conflict.

Hypothesis 4c (H4c): Groups with high levels of process conflict will have members with lower levels of satisfaction, and will be less likely to remain together as a cohesive, cooperative whole than groups with low levels of process conflict.

\section{The Moderating Effects of Conflict Culture}

The essential core of culture consists of traditional ideas and especially their attached values and the extent to which these ideas and values are accepted by a group (Kluckhohn \& Kroeber, 1952). Given that organizational culture affects group level processes, we propose that specific types of organizational culture will moderate the relationship between group faultlines and different types of group conflict, i. e, task, relationship and process conflicts. For example, if certain business units have a task conflict culture, which might be when employees recognize that task related arguments and discussions assist them in performing their work and reaching excellent decisions, and this type of behavior is a norm of their workplace and valued in the business environment, they are likely to promote critical debate and task conflict within their 
workgroups is likely to be high (Jehn, 1995). Task conflict resulting from strong group faultlines is therefore likely to be escalated.

Similarly, if the business unit has a relationship conflict culture, that is, disagreements

over personal and social issues not related to work, typically including tension, animosity and annoyance, are accepted as a behavioral norm within the workplace, then groups that have strong faultlines and strong relationship conflict, will experience even greater relationship conflict. Finally, in the case of process conflict cultures, which may include an emphasis or reward at the business-unit level for competing behaviors over allocation of responsibilities and delegation of authority, groups with strong faultines are likely to have higher levels of process conflict.

Hypothesis 5a (H5a): Task conflict culture within the business unit will moderate the relationship between group faultlines and group task conflict; that is, if there is a strong task conflict culture in the business unit, group faultlines is likely to result in high level group task conflict. In contrast, if there is a weak business unit task conflict culture, group faultlines is less likely to result in high level group task conflict.

Hypothesis 5b (H5b): Business unit relationship conflict culture will moderate the relationship between group faultlines and group relationship conflict; that is, if there is a strong business unit relationship conflict culture, group faultlines is likely to result in high level group relationship conflict. In contrast, if there is a weak business unit relationship conflict culture, group faultlines is less likely to result in high level group relationship conflict.

Hypothesis 5c (H5c): Business unit process conflict culture will moderate the relationship between group faultlines and group process conflict; that is, if there is a strong business unit process conflict culture, group faultlines is likely to result in high level group process conflict. In contrast, if there is a weak business unit process conflict culture, group faultlines is less likely to result in high level group process conflict. 


\section{Methods}

\section{Research Site}

Our sample is a large Corporate Headquarters with over 26,000 employees at all ranks within the organization in the computer industry. Employees work in a range of business units $(\mathrm{n}=12)$ such as corporate administration, finance, sales, product development, software systems, and manufacturing. The workgroups were created using a reporting system developed by the company as well as the information about the organization/business units' structures provided by key senior staff. We identified workgroups from a company listing of who reports to whom as the working groups within the organization are specified this way. We verified that these were actual working groups (i.e., they interacted on a day-to-day basis, were task interdependent, identified each other as group members, and were seen by others as workgroups) by interview and observation. We were informed that "groups" of 1 or 2 employees $(n=973)$ or groups with over 8 employees $(n=291)$ were not actual working groups. This is consistent with our definition of group (see above) and with group process theories regarding group size. In addition, given that the bases of our hypotheses are from social psychology and organization group theory, we found this appropriate. We were unable to determine whether the groups of size 8 or over could be broken down into smaller groups that may have then been appropriate to use in the tests of our research model. This sample includes 518 individuals and 78 groups with complete data who were working full-time for all or part of the time period from January 1, 1999, to December 31, 1999. The age of employees ranged from 26 to 69 years with a mean of 46 years. The employees were $71.2 \%$ male, and $28.8 \%$ female. The majority of employees ( $88 \%)$ were white; 6.9\% were African American, 2.7\% Asian, 2.3\% Hispanic, and there were no Native Americans in this subsample. The level of education ranged from grade school to the $\mathrm{Ph}$. D. level; the modal level was a Bachelor's degree. Tenure in the firm ranged from less than 1 year to 43 years with a mean of 15 years. Work functions included 22 distinct categories (e.g. customer service, finance, marketing). 


\section{Measures}

Group Faultlines. We used the company's personnel records and other archival data to locate employees' demographics on age, gender, race, function, education, and tenure. As past research showed the importance of distinguishing between the effects of faultline strength (how cleanly a group splits into subgroups) and faultline distance (how far apart subgroups are from each other), we operationalize group faultlines in terms of faultline strength and faultline distance. We use faultline algorithm and rescaling procedure to calculate faultline strength and faultline distance scores for each work group (Bezrukova, Jehn, \& Zanutto, 2001; Thatcher, Jehn, \& Zanutto, 2000).

Faultline Strength. Faultline strength was measured along six demographic characteristics (race, age, gender, level of education, tenure with the company, and functional background) using a faultline algorithm and a rescaling procedure developed by Thatcher, Jehn, and Zanutto (2000). This faultline strength measure calculates the percent of total variation in overall group characteristics accounted for by the strongest group split, in other words, the faultline strength score indicates how a group splits cleanly into two subgroups. We have calculated the faultline strength scores excluding subgroups of size one because these subgroups cannot be considered as a group based on social psychological perspective. Possible values of faultline strength ranged from .33 (weak faultline strength) to .83 (very strong faultline strength).

Faultline Distance. We measured how far apart two subgroups are from each other on demographic characteristics (race, age, gender, level of education, tenure with the company, and functional background). The faultline distance measure was adapted from multivariate statistical cluster analysis (e.g. Morrison, 1967; Jobson, 1992; Sharma, 1996) and calculated as a distance between centroids (the Euclidean distance between the two sets of averages):

To rescale the variables so that they can be reasonable combined into one distance measure, we calculated the scores so that difference in gender $=$ difference in race $=$ 
difference of 15 years of age (approx 2sd) = difference of 10 years in tenure (approx $1 \mathrm{sd})$ $=$ difference of 2 units of education (approx $1 \mathrm{sd}$ ). We have also considered that a difference in function is more important than a difference in gender or race (1.5 times as important) so that difference in function $=$ difference of 22.5 years in age $=$ difference of 15 years in tenure $=3$ units of education. Possible values of faultline distance ranged from .98 (little faultline distance) to 3.34 (very great faultline distance).

\section{Content Analyses}

As employee survey data (i.e., direct measures of conflict and what is most often used to assess group conflict) was not available, we content-analyzed the company's documents (e.g. the Leadership Program reports) to generate measures of our variables. The LP reports capture the dominant group processes in work groups including task, process, and relationship conflict, as well as group members' satisfaction. These documents are a part of a human resources-sponsored application designed to provide the company's succession planning process.

We organized the company textual data by work groups and created frequency lists for each group using the Monoconc content analysis computer program. Then, we developed a list of key words characterizing each conflict and satisfaction variable based on relevant group and organizational theories (see details for each construct in an Appendix 3), as well as the concepts used in the company's rhetoric. We conducted key word searches on all work groups to obtain the number and frequency of key words mentioned (we set the search parameters to show results with the 70 characters surrounding the search terms). Following the method of Jehn and Werner (1993), two independent raters reviewed the surrounding context and coded the text for each workgroup on each variable of interest as defined by theory. They evaluated the intensity of the conflict in each group on a scale from 1 to 7 . The interrater reliability was quite high and ranged from .89 to .97 on the variables.

To arrive at the score, raters developed a four-step procedure. They began by discussing the first two pages one group at a time. The discussion helped them formulate scoring 
rules to guide them through the rest of the process. After discussing and reaching agreement, they assigned a common score for the group on each variable. Next, they repeated the above process for four more pages containing the textual data. They then did six pages individually guided by the rules they had created. Once completed, they met again to compare the scores they assigned. When discrepancies appeared, they discussed why and modified their rules if necessary. They also modified their discrepant scores until they once again had agreement (whereas in the first two steps they had perfect agreement, for the third step, they allowed for a deviation of one). If discrepancies do not appear, the raters continue to work independently on the rest of the document. They defined the scale, for example, as (1) - equals 0 conflict. As long as phrase is relevant to conflict type, keep word and assign this if necessary to reflect the low extent or nonexistence of the conflict. (2) - slight difference of opinion - no confrontation. (3) - clear difference of opinion - no confrontation. (4) - mild or constructive criticism. (5) harsher criticism. (6) - strong disagreement - clear confrontation. (7) - approaching or actual gridlock.

Group Conflict. The conflict variables were operationalized as: (1) process conflict: conflict about how task accomplishment should proceed in the work unit, who's responsible for what, and how things should be delegated (e.g. allocate, delegate, assign, responsibility, who, process, schedule). (2) relationship conflict: interpersonal incompatibilities among group members, which typically includes tension, animosity, and annoyance among members within a group (e.g. enemy, fault, personal, backstabbing, complain, pressure). (3) task conflict: disagreements among group members about the content of the task being performed, including differences in viewpoints, ideas, and opinions (e.g. discuss, viewpoint, differ, negotiate, perspective, ends, opinion). The extracts of the textual data we used to specify conflict variables are included in Appendix 2.

Business Unit Conflict Culture. We content analyze the textual data we have received from the company. We specified three different conflict cultures: (1) process conflict culture: statements and opinions about how task accomplishment should proceed in the 
work unit, who's responsible for what, and how things should be delegated (e.g. allocate, delegate, assign, responsibility, who, process, schedule). (2) relationship conflict: interpersonal incompatibilities among group members, which typically includes tension, animosity, and annoyance among members within a group (e.g. enemy, fault, personal, backstabbing, complain, pressure). (3) task conflict: disagreements among group members about the content of the task being performed, including differences in viewpoints, ideas, and opinions (e.g. discuss, viewpoint, differ, negotiate, perspective, ends, opinion).The extracts of the textual data we used to specify conflict variables are included in Appendix 2.

Performance. We used group and individual performance ratings, bonuses and stock options as outcome variables. We also used business unit performance ratings as determined by the Board of Directors and executive management. Stock options (group records) refer to the number of options awarded. Bonus amounts (group records) are the actual bonus amounts paid out for the year. Bonus amounts are calculated by running the bonus calculation module, which is the program code that performs the actual bonus calculations. The yearly bonus is calculated on total base salary for the year and includes multiple performance indicators determined by the company. Performance ratings (individual records) are the codes associated with an employees' performance review (e.g. 5 refers to outstanding performance, and 1 refers to unsatisfactory).

Satisfaction. Content analyzed data includes indicators of employees' satisfaction. We specified two variables to indicate the employees' satisfaction: (1) positive attitudes toward work-related issues (e.g., good, well, best, better, improve, win, success, improve, gain, great, happy). (2) negative attitudes towards work-related issues (e.g., no, not, don't cannot, bad, loss, poor, fail, mislead, exploit, ineffective, weak).

\section{Results}

Table 1 displays means, standard deviations, and correlations among all variables. As expected, faultline strength and faultline distance are positively correlated with each other. Group relationship conflict is negatively associated with business unit task and 
process conflict cultures. Group process conflict is negatively correlated with all types of business unit conflict cultures. The performance measures are highly correlated indicating that the bonuses, stock options, and performance ratings measure similar aspects of performance. We examine the relationships between faultlines, group conflicts, business unit conflict cultures, and performance further using hierarchical regression analyses.

\section{-INSERT TABLE 1 ABOUT HERE}

\section{Faultlines and Conflict}

We conducted hierarchical regression analyses to test our hypotheses predicting the effects of group faultlines on relationship, task, and process conflict (H1a through H1c). Step 1 includes controls (group size), step 2 includes the main effects of faultline strength and distance. As shown in table 3, faultlines were positively and significantly related to task conflict in work groups as predicted by $\mathrm{H} 1 \mathrm{~b}$. $\mathrm{H} 1 \mathrm{a}$ and $\mathrm{H} 1 \mathrm{c}$, predicting that faultlines would increase relationship and process conflict in work groups, were not supported. However, group faultlines explained from $1 \%$ to $10 \%$ of the variance in conflict within workgroups.

-INSERT TABLE 2 ABOUT HERE

\section{Group Conflict and Performance}

Hypotheses $\mathrm{H} 2 \mathrm{a}$ and $\mathrm{H} 2 \mathrm{c}$ were partially supported by the regression analyses (see table 3). Group relationship conflict was negatively related to individual performance ratings (beta $=-.049, \mathrm{p}=\mathrm{n} . \mathrm{s}$.) and positively and significantly related to negative satisfaction (beta $=.420, \mathrm{p}<.001)$. Hypotheses $\mathrm{H} 3 \mathrm{~b}$ and $\mathrm{H} 3 \mathrm{c}$ were supported by the regression analyses (see table 4). Group task conflict was positively related to stock options (beta= $.107, \mathrm{p}=\mathrm{n} . \mathrm{s}$.), positively and significantly related to group bonuses (beta $=.223, \mathrm{p}<.001$ ) and negative satisfaction (beta $=.379, \mathrm{p}<.001$ ). Hypotheses $\mathrm{H} 4 \mathrm{a}, \mathrm{H} 4 \mathrm{~b}$, and $\mathrm{H} 4 \mathrm{c}$ were not supported by the regression analyses (see table 5). In interesting contrast to our predictions, we found that group process conflict was positively and significantly related to group bonuses, stock options, and positive performance ( $b e t a=.383, \mathrm{p}<.001$, beta $=$ $.286, \mathrm{p}<.001$, and beta $=.337, \mathrm{p}<.001$, respectively). 


\section{Moderating Effects of Business Unit Conflict Cultures}

We conducted hierarchical regression analyses to test our hypotheses predicting the moderating effects of business unit conflict cultures on the relationship between group faultlines and conflict (H5a through H5c). Step 1 includes controls (group size), step 2 includes the main effects of faultline strength and distance, and business unit conflict culture, step 3 includes the hypothesized interactions (faultline strength x conflict culture; faultline distance $\mathrm{x}$ conflict culture).

\section{--INSERT TABLE 6 ABOUT HERE}

To provide the proper treatment of our cross-level variables and to further examine the moderating effects of group values on the relationship between group faultlines and performance, we run Hierarchical Linear Modeling. This method allow the testing of our hypotheses across levels of analyses and the investigation of the influence of higher-level units (group faultlines) on lower level outcomes (individual performance ratings) while maintaining the appropriate level of analysis. Additionally, HLM is well suited for estimating effects when group sizes differ. To be continued!!!

\section{Discussion}

This is one of the first studies where we look at organizational conflict culture from a content-specific point of view. In particular, we examine three different types of organizational conflict culture, task, relationship and process conflict cultures. Second, we are furthering our empirical evidence to support group faultline theory. This is being done with a unique data set, where we can link textual data to demographics and outcomes.

Limitations - The cross-level design limits our ability to disentangle causal relationships in the model. Future designs, for example, longitudinal, can provide a better test of the model. 
Future research - We wish to investigate congruency between group level organizational culture and business unit organizational culture. We also want to explore the congruency (fit) between the group level context and business unit context as a moderator of the relationship between group faultlines and outcomes. We can create a new variable and do something similar that you did in your 1994 paper on group value consensus and group value fit but apply this, for instance, to group level culture and a high level business unit culture. For example, if there are three working groups with group culture $\mathrm{x}, \mathrm{y}, \mathrm{z}$ respectively and then a business unit culture $\mathrm{x}$, group $\mathrm{x}$ fits perfectly while groups $\mathrm{y}$ and $\mathrm{z}$ do not. We want to look specifically at groups $\mathrm{y}$ and $\mathrm{z}$ and study how they differ from $\mathrm{x}$ (This is just an idea, and we haven't come up with how exactly we can disentangle group $\mathrm{y}$ and group $\mathrm{z}$ effects). We look at the congruency between group level conflict and business unit conflict. There have been no studies done on this to our knowledge, so it is difficult to conceptualize this cross level congruency. If we can make sense of this, that would be a great contribution. To be continued!!! 


\section{References}

Blau, P. 1977. Inequality and composition: A primitive theory of social structure. New York: Free Press.

Jehn, K.A. 1997. A qualitative analysis of conflict types and dimensions in organizational groups. Administrative Science Quarterly, 42: 520-557.

Jehn, K.A., Northcraft, G. \& Neale, M. 1999. Why Differences Make a Difference: A Field Study of Diversity, Conflict, and Performance in Workgroups. Administrative Science Quarterly, 44: 741-763.

Lau, D. \& Murnighan, J.K. 1998. Demographic Diversity and Faultlines: The Compositional Dynamics of Organizational Groups. Academy of Management Review, 23(2): $325-340$.

Pelled, L. 1996. Demographic diversity, conflict, and work group outcomes: An intervening proves theory. Organizational Science, 7: 615-631.

Thatcher \& Jehn, 1998. A Model of group diversity profiles and categorization processes in bicultural organizational teams. Research on Managing Groups and Teams, 1: 1-20.

Thatcher, S.M., Jehn, KA., and Zanutto, E., 2000. Cracks in diversity research: The effects of faultlines on conflict and performance. In press.

Watson, W., Kumar, K., \& Michaelsen, L. 1993. Cultural diversity's impact on interaction process and performance: Comparing homogeneous and diverse task groups. Academy of Management Journal, 36: 590-602.

Williams, K. \& O'Reilly, C. 1998. Demography and Diversity in Organizations: A Review of 40 Years of Research. Research in Organizational Behavior, 20: 77p-140. 
Figure 1. Research Model

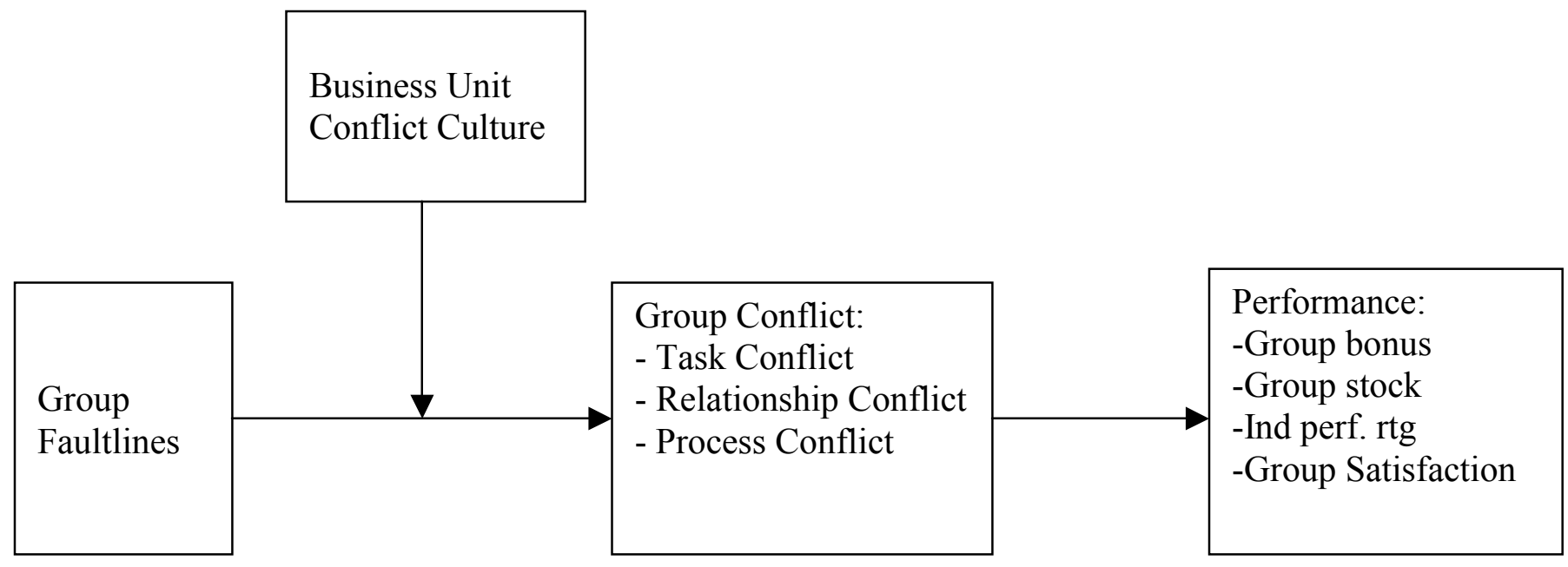




\section{Appendix 1: Episodes of Group Conflict Types, Business Unit Conflict Cultures, and Satisfaction.}

\begin{tabular}{|c|c|}
\hline Content Categories & Transcribed texts \\
\hline $\begin{array}{l}\text { Group Relationship conflict } \\
\text { (personality clashes) }\end{array}$ & $\begin{array}{l}\text { "...customer service and employee training and communications is } \\
\text { [[difficult]], stressed. XXXXX does not support this with different } \\
\text { objectives, philosophy's, etc. Resources, including IT, people, Telecomm } \\
\text { Voice and Data are stressed and pulled in different directions. We had } \\
\text { conversations with appropriate Sr Mgt on org structure to balance } \\
\text { competitiveness and the need to reduce costs with the need to run the } \\
\text { business as efficiently as possible with well trained people..." } \\
\text { “...1 media relations support person is has only been with the company for } \\
10 \text { mos \& she is just conquering the steep learning curve on some aspect. } \\
\text { She is pregnant and will be out in November for } 2 \text { months..." }\end{array}$ \\
\hline $\begin{array}{l}\text { Group Task conflict } \\
\text { (conflict of ideas) }\end{array}$ & $\begin{array}{l}\text { "... Strengthen teaming with outside Engr. sources and promote x-functional } \\
\text { partnerships within PB. Develop partnership expertise and communication } \\
\text { skills with a global [[perspective]]..." } \\
\text { "...Functional Engineering Director Replacment Requied by Mid } 2000 \text {. } \\
\text { Alternative organizations may be considered If the Functional Directors Job } \\
\text { is eliminated can the VP of engineering handle the [[work]] load of an } \\
\text { additional } 5 \text { reports..." }\end{array}$ \\
\hline $\begin{array}{l}\text { Group Process conflict } \\
\text { (conflict around the ways } \\
\text { how to do work) }\end{array}$ & $\begin{array}{l}\text { "... Core team members need to understand that }[[\text { phases }]] \text { IV \& V are as } \\
\text { important as }[[\text { phases }]] \text { II \& III..." } \\
\text { "...internal \& external customers perceive a degradation in support [[work]] } \\
\text { with Mfg \& Svc to clarify roles \& responsibilities..." } \\
\text { "...this will be a deviation from the standard operating [[procedures]]..." }\end{array}$ \\
\hline $\begin{array}{l}\text { Business Unit Relationship } \\
\text { conflict culture (personality } \\
\text { clashes) }\end{array}$ & $\begin{array}{l}\text { "No direction, lost.. no focus, If I call Human Resources to ask a simple } \\
\text { policy question, they will inform my boss that I am making [[trouble]], they } \\
\text { will not give me ANY help. They are traitors!!!" } \\
\text { "each division acts like the other is the [[enemy]]. How can we trust anyone } \\
\text { when no on e gets along. I think the } \$ \$ \text { has been the priority not the } \\
\text { employees. If you have employees that enjoy their job w/o the feeling of } \\
\text { being fired all the time or being treated unfairly your } \$ \$ \text { will fall into place } \\
\text { and we will have a top notch company." }\end{array}$ \\
\hline $\begin{array}{l}\text { Business Unit Task conflict } \\
\text { culture (conflict of ideas) }\end{array}$ & $\begin{array}{l}\text { "Midwest divisions shouldn't be put under east coast management. Totally } \\
\text { different people with different [[ideas]] that don't relate or mix well. After } \\
\text { working under } 2 \text { regions I find that both regions have totally different } \\
\text { company policies. Different paperwork, different objectives. United we } \\
\text { stand, divided we fall". } \\
\text { "Current environment cultivates culture of fear and inaction environment; } \\
\text { Employees who challenge [[ideas]] and criticize big decisions on the points } \\
\text { of failure (even if they want to provide solutions) are viewed as non-team } \\
\text { players and pay a heavy 'political' price". }\end{array}$ \\
\hline
\end{tabular}




\begin{tabular}{|c|c|}
\hline $\begin{array}{l}\text { Business Unit Process } \\
\text { conflict culture (conflict } \\
\text { around the ways how to do } \\
\text { work) }\end{array}$ & $\begin{array}{l}\text { "The norm is to throw a program or [[process]] out to the employees and see } \\
\text { what happens. Consequently we have several different interpretations of the } \\
\text { same program and people implementing and practicing the program } \\
\text { improperly". } \\
\text { "There are too many inconsistencies within XXXXXX. For example: Dress } \\
\text { Code, Job Description, what is covered under HR guidelines and what is not. } \\
\text { (That seems to vary from manager to manager) Our HR department quite } \\
\text { frankly is not trusted by anyone because as soon as you go to them with any } \\
\text { type of problem or question, they go right to your manager." } \\
\text { "One day we are instructed to do something one [[way]] but yet when we do } \\
\text { the job they complain that we are not doing as well as before. Well, if you } \\
\text { want us to do a task one way that takes longer do not expect the same call } \\
\text { volume. XXXXXX changes the way we do our tasks and then reverts to the } \\
\text { old way and then says we are not doing our job right. Also with this call } \\
\text { monitoring we are being penalized for pausing before responding to the } \\
\text { customer, I was taught to think before you open your mouth". }\end{array}$ \\
\hline Satisfaction (positive) & $\begin{array}{l}\text { "... Our inserter servicing is currently handled [[effectively]] by our large } \\
\text { dealers in Latin America and will be supported, if needed, by our Mexican } \\
\text { company and/or the Production Mail organization in Danbury..." } \\
\text { "... Continue the high growth rates that Postal Payment Solutions has } \\
\text { [[achieved]] over the past several years despite high Purchase Power } \\
\text { penetration..." }\end{array}$ \\
\hline Satisfaction (negative) & $\begin{array}{l}\text { "... Business units [[resist]] using consultants because of the cost involved } \\
\text { limiting the opportunities for Consultants and reducing their potential to } \\
\text { assist the business units..." } \\
\text { “... Additional workspace needed. We have run out of [[work]] and file } \\
\text { space and therefore cannot comfortably perform..." }\end{array}$ \\
\hline
\end{tabular}


Appendix 2. Examples from the Keyword List.

\begin{tabular}{|c|c|c|c|c|}
\hline $\begin{array}{l}\text { onflict } \\
\text { ickstabbing } \\
\text { inter } \\
\text { rrb } \\
\text { cker } \\
\text { mplain } \\
\text { nflict } \\
\text { stroy } \\
\text { structive } \\
\text { fficult } \\
\text { sgruntled } \\
\text { slike } \\
\text { srupt } \\
\text { emy } \\
\text { ult } \\
\text { ght } \\
\text { iend } \\
\text { umbling } \\
\text { ndrance } \\
\text { rsonal } \\
\text { rsonality } \\
\text { essure } \\
\text { oblem } \\
\text { lationship } \\
\text { cial } \\
\text { ouble } \\
\text { ssk Conflict } \\
\text { ffer } \\
\text { sagree } \\
\text { scuss } \\
\text { dds } \\
\text { nerate } \\
\text { als } \\
\text { eas } \\
\text { gotiate } \\
\text { oinion } \\
\text { rspective } \\
\text { sk } \\
\text { ew } \\
\text { int } \\
\text { ork }\end{array}$ & $\begin{array}{l}\text { allocess Contlict } \\
\text { assign } \\
\text { delegate } \\
\text { direct } \\
\text { distribute } \\
\text { divide } \\
\text { duty } \\
\text { means } \\
\text { order } \\
\text { organize } \\
\text { plan } \\
\text { procedures } \\
\text { process } \\
\text { reorganize } \\
\text { responsibility } \\
\text { schedule } \\
\text { supplies } \\
\text { way } \\
\text { what } \\
\text { when } \\
\text { who } \\
\text { Team Identity } \\
\text { support } \\
\text { supporting } \\
\text { process } \\
\text { processes } \\
\text { we } \\
\text { our } \\
\text { us } \\
\text { team } \\
\text { teams } \\
\text { teamwork } \\
\text { group } \\
\text { groups } \\
\text { communication } \\
\text { communications } \\
\text { communicate } \\
\text { relation } \\
\text { relations } \\
\text { relationship } \\
\text { relationships }\end{array}$ & $\begin{array}{l}\text { responsibilities } \\
\text { help } \\
\text { helping } \\
\text { person } \\
\text { involved } \\
\text { people } \\
\text { meetings } \\
\text { Satisfaction } \\
\text { (negative) } \\
\text { can't } \\
\text { cannot } \\
\text { didn't } \\
\text { won't } \\
\text { don't } \\
\text { not } \\
\text { no } \\
\text { non } \\
\text { bad } \\
\text { difficult } \\
\text { difficulty } \\
\text { down } \\
\text { downsizing } \\
\text { anxiety } \\
\text { behind } \\
\text { lack } \\
\text { lacking } \\
\text { mislead } \\
\text { gap } \\
\text { gaps } \\
\text { without } \\
\text { decline } \\
\text { declining } \\
\text { decrease } \\
\text { decreased } \\
\text { decreasing } \\
\text { eliminate } \\
\text { eliminating } \\
\text { eliminated } \\
\text { discontinuation } \\
\text { reduce } \\
\text { reducing } \\
\text { ad }\end{array}$ & $\begin{array}{l}\text { duction } \\
\text { duced } \\
\text { sist } \\
\text { sisted } \\
\text { ss } \\
\text { sses } \\
\text { se } \\
\text { st } \\
\text { ss } \\
\text { ssen } \\
\text { egative } \\
\text { egatively } \\
\text { por } \\
\text { oorly } \\
\text { lversely } \\
\text { nnstrains } \\
\text { onstrain } \\
\text { correctly } \\
\text { correct } \\
\text { il } \\
\text { ilure } \\
\text { iled } \\
\text { effective } \\
\text { effectively } \\
\text { sufficient } \\
\text { sufficiently } \\
\text { ability } \\
\text { able } \\
\text { adequate } \\
\text { adequately } \\
\text { consistent } \\
\text { consistently } \\
\text { experience } \\
\text { accurate } \\
\text { accurately } \\
\text { aderqualified } \\
\text { aachieved } \\
\text { areliable } \\
\text { eak } \\
\text { w } \\
\text { ress } \\
\text { rnover } \\
\text { ssatisfaction }\end{array}$ & \begin{tabular}{|l} 
Satisfaction \\
(positive) \\
good \\
well \\
best \\
better \\
progress \\
accelerate \\
accelerated \\
accelerating \\
accomplish \\
accomplished \\
accomplishing \\
improve \\
improved \\
improving \\
increase \\
increasing \\
increased \\
generate \\
generated \\
generating \\
effective \\
effectively \\
effectiveness \\
efficient \\
efficiency \\
success \\
successful \\
great \\
greater \\
gain \\
gains \\
achieve \\
achieving \\
high \\
win \\
positive \\
best-of-breed \\
strength \\
accurate \\
accomplish \\
happy
\end{tabular} \\
\hline
\end{tabular}


Table 1. Means, Standard Deviations, and Zero-Order Correlations Among Variables.

\begin{tabular}{|c|c|c|c|c|c|c|c|c|c|c|c|c|c|c|}
\hline \multirow[t]{2}{*}{ Variables } & \multirow[t]{2}{*}{$\mathrm{M}$} & \multirow[t]{2}{*}{ SD } & \multicolumn{12}{|c|}{ Correlations } \\
\hline & & & 1 & 2 & 3 & 4 & 5 & 6 & 7 & 8 & 9 & 10 & 11 & 12 \\
\hline 1.Faultline Strength & 0.49 & 0.12 & & & & & & & & & & & & \\
\hline 2.Faultline Distance & 1.89 & 0.47 & $0.49 * *$ & & & & & & & & & & & \\
\hline 3.Group Relationship & 1.52 & 1.26 & $-0.13^{*}$ & $-0.17^{* *}$ & & & & & & & & & & \\
\hline \multicolumn{15}{|l|}{ Conflict } \\
\hline 4.Group Task Conflict & 2.71 & 1.84 & -0.03 & $-0.21^{* *}$ & 0.08 & & & & & & & & & \\
\hline 5.Group Process Conflict & 3.02 & 1.49 & -0.05 & 0.00 & -0.08 & $0.23 * *$ & & & & & & & & \\
\hline 6. Business Unit & 3.14 & 1.30 & $0.15^{* *}$ & 0.10 & -0.08 & 0.03 & $-0.09 *$ & & & & & & & \\
\hline \multicolumn{15}{|l|}{ Relationship Conflict } \\
\hline \multicolumn{15}{|l|}{ Culture } \\
\hline 7. Business Unit Task & 3.91 & 1.44 & $-0.16^{* *}$ & $-0.21^{* *}$ & $-0.12^{* *}$ & -0.04 & $-0.20^{* *}$ & $0.09 *$ & & & & & & \\
\hline \multicolumn{15}{|l|}{ Conflict Culture } \\
\hline 8. Business Unit Process & 4.67 & 1.14 & 0.04 & -0.04 & $-0.11^{* *}$ & 0.04 & $-0.14 * *$ & -0.02 & $0.75^{* *}$ & & & & & \\
\hline \multicolumn{15}{|l|}{ Conflict Culture } \\
\hline 9.Bonuses & 27466.94 & 34336.98 & -0.05 & 0.01 & $0.11 *$ & $0.20^{* *}$ & $0.36^{* *}$ & $0.27 * *$ & $-0.17^{* *}$ & $-0.13^{* *}$ & & & & \\
\hline 10.Stocks & 1372.12 & 1744.35 & $-0.16^{* *}$ & -0.05 & 0.02 & $0.11^{*}$ & $0.31^{* *}$ & $0.12 * *$ & $-0.11^{*}$ & $-0.17^{* *}$ & $0.84 * *$ & & & \\
\hline 11.Performance Ratings & 3.88 & 0.34 & 0.07 & -0.04 & -0.04 & -0.04 & 0.02 & $0.11^{*}$ & -0.04 & -0.01 & $0.16^{* *}$ & 0.06 & & \\
\hline $\begin{array}{l}\text { 12.Satisfaction } \\
\text { (negative) }\end{array}$ & 3.62 & 1.93 & -0.09 & $-0.18^{* *}$ & $0.33^{* *}$ & $0.40^{* *}$ & $0.23^{* *}$ & $-0.17^{* *}$ & 0.04 & 0.04 & $0.32 * *$ & $0.21^{* *}$ & 0.05 & \\
\hline 13.Satisfaction (positive) & 4.13 & 1.96 & 0.07 & 0.08 & $0.23 * *$ & $0.26^{* *}$ & $0.30^{* *}$ & -0.04 & $-0.14 * *$ & -0.05 & $0.45 * *$ & $0.35 * *$ & 0.06 & $0.41^{* *}$ \\
\hline
\end{tabular}

Table 2. Hierarchical Regression Analyses Predicting Conflict $(\mathrm{N}=518)$

\begin{tabular}{llll}
\hline & Relationship Conflict & Task Conflict & Process Conflict \\
\hline Step 1: Controls & & & -.057 \\
Group Size & .037 & .072 & .002 \\
Adjusted R2 & .002 & .002 & 1.024 \\
F & .428 & 1.609 & -.114 \\
Step 2: Main Effects & & & $.092^{*}$ \\
Faultline Strength (FauS) & -.020 & $.197 * *$ & .009 \\
Faultline Distance (FauD) & $-.190^{* *}$ & $-.380^{* * *}$ & 1.368 \\
Change in R2 & .037 & .085 & .012 \\
F change & $5.883^{* *}$ & $14.409 * * *$ & .003 \\
R2 & .038 & .090 & 1.254 \\
Adjusted R2 & .029 & .081 & $10.188^{* * *}$ \\
F & $4.069 * *$ & & \\
\hline
\end{tabular}


Table 3. Regression Analyses Predicting Performance and Satisfaction for Relationship Conflict.

\begin{tabular}{|c|c|c|c|c|c|}
\hline & Bonuses & Stock Options & $\begin{array}{l}\text { Performance } \\
\text { Ratings }\end{array}$ & $\begin{array}{l}\text { Satisfaction } \\
\text { (negative) }\end{array}$ & $\begin{array}{l}\text { Satisfaction } \\
\text { (positive) }\end{array}$ \\
\hline \multicolumn{6}{|l|}{ Step 1: Controls } \\
\hline Group Size & $.144^{*}$ & .045 & -.005 & $.159 * *$ & $.212 * * *$ \\
\hline Adjusted R2 & .017 & -.001 & -.003 & .022 & .042 \\
\hline $\mathrm{F}$ & $6.519 *$ & .642 & .007 & $8.054 * *$ & $14.538 * * *$ \\
\hline \multicolumn{6}{|l|}{ Step 2: Main Effects } \\
\hline Faultline Strength (FauS) & -.006 & $-.178 *$ & .134 & .120 & $2.332 *$ \\
\hline Faultline Distance (FauD) & -.040 & .038 & -.119 & $-.331 * * *$ & -1.226 \\
\hline Change in R2 & .002 & .025 & .013 & .069 & .017 \\
\hline F change & .273 & $3.916^{*}$ & 2.000 & $11.651 * * *$ & 2.732 \\
\hline $\mathrm{R} 2$ & .022 & .027 & .013 & .094 & .061 \\
\hline Adjusted R2 & .013 & .017 & .003 & .085 & .052 \\
\hline $\mathrm{F}$ & 2.345 & $2.829 *$ & 1.336 & $10.637 * * *$ & $6.722 * * *$ \\
\hline \multicolumn{6}{|l|}{ Step 3:Main effects } \\
\hline $\begin{array}{l}\text { Relationship Conflict } \\
\text { (RC) }\end{array}$ & .049 & -.064 & -.049 & $.420 * * *$ & $.263 * * *$ \\
\hline Change in R2 & .002 & .004 & .002 & .170 & .067 \\
\hline F change & .719 & 1.239 & .724 & $70.742 * * *$ & $23.452 * * *$ \\
\hline $\mathrm{R} 2$ & .025 & .031 & .015 & .264 & .128 \\
\hline Adjusted R2 & .012 & .018 & .002 & .254 & .117 \\
\hline $\mathrm{F}$ & 1.937 & $2.433 *$ & 1.182 & $27.469 * * *$ & $11.272 * * *$ \\
\hline
\end{tabular}

Table 4. Regression Analyses Predicting Performance and Satisfaction for Task Conflict.

\begin{tabular}{|c|c|c|c|c|c|}
\hline & Bonuses & Stock Options & $\begin{array}{l}\text { Performance } \\
\text { Ratings }\end{array}$ & $\begin{array}{l}\text { Satisfaction } \\
\text { (negative) }\end{array}$ & $\begin{array}{l}\text { Satisfaction } \\
\text { (positive) }\end{array}$ \\
\hline \multicolumn{6}{|l|}{ Step 1: Controls } \\
\hline Group Size & $.144 *$ & .045 & -.005 & $.159 * *$ & $.212 * * *$ \\
\hline Adjusted R2 & .017 & -.001 & -.003 & .022 & .042 \\
\hline $\mathrm{F}$ & $6.519 *$ & .642 & .007 & $8.054 * *$ & $14.54 * * *$ \\
\hline \multicolumn{6}{|l|}{ Step 2: Main Effects } \\
\hline Faultline Strength (FauS) & -.006 & $-.178 *$ & .134 & .120 & $.161 *$ \\
\hline Faultline Distance (FauD) & -.040 & .038 & -.119 &.$-.331 * * *$ & -.088 \\
\hline Change in R2 & .002 & .025 & .013 & .069 & .017 \\
\hline F change & .273 & $3.916^{*}$ & 2.000 & $11.651 * * *$ & 2.732 \\
\hline $\mathrm{R} 2$ & .022 & .027 & .013 & .094 & .061 \\
\hline Adjusted R2 & .013 & .017 & .003 & .085 & .052 \\
\hline $\mathrm{F}$ & 2.345 & $2.829 *$ & 1.336 & $10.637 * * *$ & $6.722 * * *$ \\
\hline \multicolumn{6}{|l|}{ Step 3:Main effects } \\
\hline Task Conflict (TC) & $.223 * * *$ & .107 & -.023 & $.379 * * *$ & $.009 *$ \\
\hline Change in $\mathrm{R} 2$ & .045 & .010 & .000 & .130 & .021 \\
\hline F change & 14.935 & 3.316 & .148 & $51.577 * * *$ & $6.979 * *$ \\
\hline $\mathrm{R} 2$ & .068 & .037 & .013 & .224 & .082 \\
\hline Adjusted R2 & .056 & .025 & .000 & .214 & .070 \\
\hline $\mathrm{F}$ & $5.572 * * *$ & $2.967 *$ & 1.036 & $22.182 * * *$ & $6.884 * * *$ \\
\hline
\end{tabular}


Table 5. Regression Analyses Predicting Performance and Satisfaction for Process Conflict.

\begin{tabular}{llllll}
\hline & Bonuses & Stock Options & $\begin{array}{l}\text { Performance } \\
\text { Ratings }\end{array}$ & $\begin{array}{l}\text { Satisfaction } \\
\text { (negative) }\end{array}$ & $\begin{array}{l}\text { Satisfaction } \\
\text { (positive) }\end{array}$ \\
\hline Step 1: Controls & & & & & \\
Group Size & $.144^{*}$ & .045 & -.005 & $.159^{* *}$ & $.212^{* * *}$ \\
Adjusted R2 & .017 & -.001 & -.003 & .022 & .042 \\
F & $6.519^{*}$ & .642 & .007 & $8.054^{* *}$ & $14.538^{* * *}$ \\
Step 2: Main Effects & & & & & \\
Faultline Strength (FauS) & -.006 & $-.178^{*}$ & .134 & .120 & $.161^{*}$ \\
Faultline Distance (FauD) & -.040 & .038 & -.119 & $-.331 * * *$ & -.088 \\
Change in R2 & .002 & .025 & .013 & .069 & .017 \\
F change & .273 & $3.916^{*}$ & 2.000 & $11.651^{* * *}$ & 2.732 \\
R2 & .022 & .027 & .013 & .094 & .061 \\
Adjusted R2 & .013 & .017 & .003 & .085 & .052 \\
F & 2.345 & $2.829^{*}$ & 1.336 & $10.637^{* * *}$ & $6.722^{* * *}$ \\
\hline Step 3:Main effects & & & & & \\
Process Conflict (PC) & $.383^{* * *}$ & $.286^{* * *}$ & .066 & $.144^{*}$ & $.337^{* * *}$ \\
Change in R2 & .145 & .081 & .004 & .020 & .112 \\
F change & $53.472 * * *$ & $27.870^{* * *}$ & 1.331 & 7.073 & $41.719^{* * *}$ \\
R2 & .167 & .108 & .017 & .114 & .174 \\
Adjusted R2 & .157 & .096 & .004 & .103 & .163 \\
F & $15.426^{* * *}$ & $9.274 * * *$ & 1.336 & $9.903 * * *$ & $16.137^{* * *}$ \\
\hline$*$ p & & & &
\end{tabular}
${ }^{*} \mathrm{p}<.05 ; * * \mathrm{p}<.01 ; * * * \mathrm{p}<.001$. 
Table 6. Hierarchical Regression Analyses $(\mathrm{N}=518)$

\begin{tabular}{|c|c|c|c|c|c|}
\hline & $\begin{array}{l}\text { Relationship } \\
\text { Conflict }\end{array}$ & & $\begin{array}{l}\text { Task } \\
\text { Conflict }\end{array}$ & & Process Conflict \\
\hline Step 1: Controls & & Step 1: Controls & & Step 1: Controls & \\
\hline Group Size & .037 & Group Size & .072 & Group Size & -.057 \\
\hline Adjusted R2 & .002 & Adjusted R2 & .002 & Adjusted R2 & .002 \\
\hline $\mathrm{F}$ & .428 & $\mathrm{~F}$ & 1.609 & $\mathrm{~F}$ & 1.024 \\
\hline Step 2: Main Effects & & Step 2: Main Effects & & Step 2: Main Effects & \\
\hline Faultline Strength (FauS) & .038 & Faultline Strength (FauS) & $.197 * *$ & Faultline Strength (FauS) & -.099 \\
\hline Faultline Distance (FauD) & $-.216^{* *}$ & Faultline Distance (FauD) & $-.371 * * *$ & Faultline Distance (FauD) & .075 \\
\hline Business Unit Relationship & & Business Unit Task Conflict Culture & & Business Unit Process Conflict & \\
\hline Conflict Culture (BU_RCC) & $-.228 * * *$ & $\left(\mathrm{BU} \_\mathrm{TCC}\right)$ & .032 & Culture (BU_PCC) & $-.124 *$ \\
\hline Change in R2 & .084 & Change in R2 & .086 & Change in $\mathrm{R} \overline{2}$ & .024 \\
\hline F change & $9.427 * * *$ & F change & $9.693 * * *$ & F change & 2.527 \\
\hline $\mathrm{R} 2$ & .086 & $\mathrm{R} 2$ & .091 & $\mathrm{R} 2$ & .027 \\
\hline Adjusted R2 & .074 & Adjusted R2 & .079 & Adjusted R2 & .015 \\
\hline $\mathrm{F}$ & $7.186^{* * *}$ & $\mathrm{~F}$ & $7.706 * * *$ & $\mathrm{~F}$ & 2.155 \\
\hline Step 3. Interactions & & Step 3. Interactions & & Step 3. Interactions & \\
\hline FauS X BU_RCC & .168 & FauS X BU_TCC & .041 & FauS X BU_PCC & -.281 \\
\hline FauD X BU_RCC & .422 & FauD X BU_TCC & -.291 & FauD X BU_PCC & -.424 \\
\hline Change in $\mathrm{R} \overline{2}$ & .010 & Change in $\mathrm{R} \overline{2}$ & .005 & Change in $\mathrm{R} \overline{2}$ & .013 \\
\hline F change & 1.618 & F change & .788 & F change & 2.125 \\
\hline $\mathrm{R} 2$ & .095 & $\mathrm{R} 2$ & .096 & $\mathrm{R} 2$ & .041 \\
\hline Adjusted R2 & .077 & Adjusted R2 & .078 & Adjusted R2 & .022 \\
\hline $\mathrm{F}$ & $5.349 * * *$ & $\mathrm{~F}$ & $5.393 * * *$ & $\mathrm{~F}$ & $2.156^{*}$ \\
\hline
\end{tabular}

$* \mathrm{p}<.05 ; * * \mathrm{p}<.01 ; * * * \mathrm{p}<.001$ 